\title{
Nurse care for the hospitalized elderly's spiritual dimension
}

\author{
O cuidado da enfermeira à dimensão espiritual da pessoa idosa hospitalizada \\ Cuidado de la enfermera a la dimensión espiritual del anciano hospitalizado
}

Sylvia Maria Cardoso Bastos Veras'
ORCID: 0000-0002-5326-5235

Tânia Maria de Oliva Menezes' ORCID: 0000-0001-5819-0570

Raúl Fernando Guerrero-Castañeda ${ }^{1,11}$ ORCID: 0000-0003-3996-5208

Mateus Vieira Soares' ORCID: 0000-0001-7006-2563

Florencio Reverendo Anton Neto' ORCID: 0000-0002-5492-1767

Gildásio Souza Pereira' ORCID: 0000-0001-8754-0998

'Universidade Federal da Bahia. Salvador, Bahia, Brazil. "Universidad de Guanajuato. Celaya, Guanajuato, Mexico.

How to cite this article:

Veras SMCB, Menezes TMO, Guerrero-Castañeda RF, Soares MV, Anton Neto FR, Pereira GS. Nurse care for the hospitalized elderly's spiritual dimension.

Rev Bras Enferm. 2019;72(Suppl 2):236-42. doi: http://dx.doi.org/10.1590/0034-7167-2018-0685

\section{Corresponding Author:}

Tânia Maria de Oliva Menezes E-mail: tomenezes50@gmail.com

Submission: 09-02-2018

Approval: 10-15-2018

\section{ABSTRACT}

Objective: to analyze the nurse care for the spiritual hospitalized elderly's dimension. Method: a qualitative study, based on Jean Watson's Theory of Human Caring. The study included 17 nurses working in a geriatric center in Salvador City, Bahia State, Brazil. The collection of testimonies occurred between January and April of 2018, through an interview. Results: spiritual care were dialogue, encouragement and respect for religious activities, embracement, empathy. One of the obstacles to providing this care was the lack of preparation in accessing the elderly's spiritual dimension. Final considerations: spirituality is a dimension of human and holistic nursing care. Caring for the spirit contributes to foster transpersonal care. The difficulty may be in the lack of nurses' preparation. It is necessary that they cultivate and live their own spirituality, transmitting the understanding in each care relationship.

Descriptors: Nurses; Nursing Care; Elderly; Spirituality; Religion.

\section{RESUMO}

Objetivo: analisar o cuidado da enfermeira à dimensão espiritual da pessoa idosa hospitalizada. Método: estudo qualitativo, fundamentado na Teoria do Cuidado Humano Transpessoal de Jean Watson. Fizeram parte do estudo 17 enfermeiras que trabalham em um centro geriátrico de Salvador, Bahia, Brasil. A coleta de depoimentos ocorreu entre janeiro e abril de 2018, através de entrevista. Resultados: os cuidados espirituais desvelados foram: diálogo, estímulos e respeito às atividades religiosas, acolhimento, empatia. Um dos obstáculos à prestação desses cuidados foi o despreparo em acessar a dimensão espiritual da pessoa idosa. Considerações finais: a espiritualidade é uma dimensão do cuidado humano e holístico de enfermagem. Cuidar do espírito contribui para fomentar o cuidado transpessoal. A dificuldade pode estar na falta de preparo de enfermeiras e enfermeiros, sendo necessário que cultivem e vivam sua própria espiritualidade, transmitindo a compreensão em cada relação de cuidado.

Descritores: Enfermeiras e Enfermeiros; Cuidados de Enfermagem; Idoso; Espiritualidade; Religião.

\section{RESUMEN}

Objetivo: analizar el cuidado de la enfermera a la dimensión espiritual del anciano hospitalizado. Método: estudio cualitativo, fundamentado en la Teoría del Cuidado Humano Transpersonal de Jean Watson. Se realizaron parte del estudio 17 enfermeras que trabajan en un centro geriátrico de la ciudad de Salvador, estado de Bahia, Brasil. La recolección de testimonios ocurrió entre enero y abril de 2018, a través de una entrevista. Resultados: los cuidados espirituales desvelados fueron: diálogo, estímulos y respeto a las actividades religiosas, acogida, empatía. Uno de los obstáculos a la prestación de esos cuidados fue el despreparo en acceder a la dimensión espiritual del anciano. Consideraciones finales: la espiritualidad es una dimensión del cuidado humano y holístico de enfermería. El cuidado del espíritu contribuye a fomentar el cuidado transpersonal. La dificultad puede estar en la falta de preparación de enfermeras. Es necesario que cultiven y vivan su propia espiritualidad, transmitiendo la comprensión en cada relación de cuidado.

Descriptores: Enfermeras y Enfermeros; Cuidados de Enfermería; Ancianos; Espiritualidad; Religión. 


\section{INTRODUCTION}

Consciousness / spiritual dimension and spiritual self-care, colleagues and patients are at the center of a competent and safe nursing practice ${ }^{(1)}$. This dimension contemplates spirituality and religiousness. In this way, spirituality is innate to the human being, it is constituted as a resource for the search of meaning to life, not having a direct link with religiousness, but with the individual's own need ${ }^{(2)}$. It can be used as a tool of adaptation to adverse circumstances of life $^{(3)}$.

In this sequence, religiousness is an expression of the relation of involvement with the institutional religion, pointed as a form of expression and manifestation of spirituality ${ }^{(4)}$. Another form of understanding is as a source of meaning for life, as it seeks to respond to existential concerns about human finiteness ${ }^{(5)}$.

The nurse, when assisting the patient 24 hours a day, must have a scientific basis to act through a holistic look, contemplating the spiritual dimension that, when approached, contributes to satisfy the spiritual needs of the individual(6). The holistic look is fundamental, for when spirituality is valued, personal experiences of pain and suffering can become bearable ${ }^{(7)}$.

In the life of the elderly, religion/religiousness is internalized and it is up to the health professionals and, above all, the nurse to develop spiritual care, providing care that contemplates specificity and subjectivity of the individual considered relevant ${ }^{(8)}$.

In this context, spiritual nursing care is one that recognizes and attends to the needs of the spirit in times of sickness and sadness, and may also include need for meaning, support of faith, prayer or simply a sensitive listening. This care begins by encouraging human contact in compassionate relationships and moves where needs require ${ }^{(9)}$. The nurse develops the assistance based on the Systematization of Nursing Care (SNC), whose starting point is the collection of patient data. In this first moment, during this collection, the nurse detects the needs of the person, which is why he is able to approach the assessment of spirituality as a fundamental part of the human being subject to care.

Once these needs are identified, the nurse should determine the nursing diagnosis to implement patient care. NANDA-I Nursing Diagnoses: Definitions and Classifications, in its classification, defines some diagnoses: Spiritual Suffering, Impaired Religiousness, Risk of Impaired Religiousness, Improved Religiousness ${ }^{(10)}$, among others. From the validation, nurses should implement actions for spiritual care.

The research in question is justified by the importance of knowing care provided by the nurse to the elderly's spiritual dimension. When using the recommendations of the World Health Organization (WHO), it is necessary that this is not only a vertex in health care, but must be valued, incorporated, investigated and constantly questioned ${ }^{(11)}$. In view of the above, the question is: how does the nurse take care of the hospitalized elderly's spiritual dimension?

\section{OBJECTIVE}

To analyze the nurse care for the spiritual hospitalized elderly's dimension.

\section{METHOD}

\section{Ethical aspects}

The study complied with the ethical precepts of research with human beings, according to norms and guidelines present in Resolution 466 of the Brazilian Health Board (Conselho Nacional de Saúde) of 2012, which regulates research with human beings, being submitted and approved by the Ethics and Research Committee of the institution where the study was developed under Opinion 2,302,775. The conditions of anonymity and confidentiality of the testimonies were preserved, and fictitious names of gems were attributed to participants.

\section{Type of study}

This is an exploratory and descriptive study with a qualitative approach and theoretical framework by Jean Watson's Theory of Transpersonal Caring.

\section{Study setting}

The study site was a philanthropic institution, in the city of Salvador, Bahia, Brazil. The center serves the elderly in various modalities, such as the hospitalization unit for acute patients, rehabilitation unit, chronic unit, palliative care and long stay. It has 20 nurses in the staff, of which 17 participated in the research. Participants were contacted by the researcher and invited to participate in the study. There was no refusal or abandonment of participants during the study. The inclusion criteria were nurses working at the geriatric center for at least 6 months. As exclusion criterion: to be formally removed at the time of collection for any legal reason.

\section{Collection and organization of data}

The testimonies were collected between January and April 2018 and were held in a reserved place through a semi-structured interview. It was guided by a previously prepared form, with subjective questions to facilitate the speech of the collaborators, composed of two parts: the first contained questions regarding sociodemographic data of participants; and the second, a guiding question on the subject: how do you take care of the spiritual needs of the elderly?

The testimonies were recorded by means of recording. From there, the listening and the transcriptions of the speech were performed. The fidelity of the speech was maintained.

\section{Data analysis}

In the next step, the statements were analyzed according to the Thematic Content Analysis, according to the recommended steps: pre-analysis, material exploration/coding/analytical description and treatment of the obtained results/interpretation ${ }^{(12)}$ and theoretical framework ${ }^{(13-14)}$.

\section{RESULTS}

\section{Sociodemographic characterization of participants}

Participants were between 23 and 38 years of age. The time of care in the institution ranged from eight months to nine years. 
Of the interviewees, 15 reported having a religion, and two had no religion, the majority being Catholic (nine).

Regarding the frequency of religious activities, 03 refer to attending once a week, once, twice a week, once, three times a week, twice, once a month, once a month twice, once every three one, once every six months, two, sporadically, two do not attend any activity and one did not report.

Given the study and analysis of the data, the answer to the question of the study seized a category: Nurse's care for the hospitalized elderly's spiritual dimension, who understood care through dialogue, embracement, encouragement of prayer, respect for religious activities and empathy.

One of the ways of taking care of the spiritual dimension, pointed out by the nurses, is the dialogue with the patients, which runs through the words of encouragement to faith, to belief, strength and embracement:

I am always willing to listen, to talk, to welcome the patient. I try to do my best to have faith, even though I have no religion. I speak to the patient to pray if he is very Catholic, pray, that everything will work out. (Amethyst)

During the moment of a bath that we are there talking to a patient, we try to be always trying to give a more humanized welcome, more oriented towards this side too. (Azurite)

I try to offer words of comfort, because he is hospitalized. He is not attending church, but when he leaves, he will attend. Then I speak of his God. (Turquoise)

Or ask for help, give a word of comfort, give a positive word. It's getting better but have faith. (Aquamarine)

Just the fact that people speak words of comfort, to believe in something that does not necessarily have to be what I believe, but what he believes in, right? (Moon stone)

I think we take great care through dialogue, conversation. (Quartz)

Patient is more frail, more crying, worried, anxious, that's when I talk about the spiritual issue. (Jade)

The sense of perception was present in the dialogue when they perceive the state of vulnerability and the diversity of spiritual needs of the elderly. Jade emphasizes behaviors of frailty, worry and anxiety. However, relevant active listening in the interpersonal and valued relationship in the Watson's Theory of Transpersonal Caring was inexpressive.

Embracement was also identified by Amethyst, Azurite, Turquoise and Sea Water as manifestations of spiritual care because they stressed the importance of this, in view of the frailty that the elderly presents during hospitalization. It is emphasized that this was manifested only with words of comfort, encouragement to belief, dialogue, but not with the appreciation of listening or touch, relevant in human care.

The Aquamarine and Crystal discourses converge with literature, as regards welcoming the nurse/patient relationship, favoring spiritual care:

Think that you are well, that you are improving, that you will succeed. It is at this moment that we gain confidence. (Aquamarine)
They are chronic patients, so we know them, they miss us. When they come to talk, they have that intimacy. Sometimes it's someone in a lot of pain, sad because the family is not here. Then I be like: have faith, a God who will solve. Believe in God. (Crystal)

When the patient perceives care based on the proximity of professional and embracement, there is a feeling of support, comfort and safety. These contribute to strengthening the nurse/ patient relationship.

In the statements below, the collaborators highlight other forms of embracement, such as meeting spiritual needs through encouragement of prayer and permission to participate in religious activities:

Always when I realize they are with the Bible, I have already prayed, I have already spoken; everything will be okay, trust in God. So we have to respect their wishes too. (Agate)

Releasing their presence in the masses, respecting the schedules of the elderly who have to pray theirs. (Malachite)

Look, pray if you're very Catholic, pray, everything is going to be okay. (Amethyst)

The patient asks for a prayer. We go and do it. (Aquamarine

A song that comes to reassure, whether of religion or not. If it is a biblical issue, bring some verses from the Bible. (Turmaline)

The nurses attend, as much as possible, various requests for spiritual needs. As the institution has weekly mass routines, it facilitates the attendance of such needs to those who are Catholic. Seven nurses referred to the referral to this religious practice.

As for encouragement to prayer, Malachite and Amethyst accused, but only Agate and Aquamarine reported having already prayed with the patient. Prayer is an important manifestation of faith, and can be encouraged in the suffering of the elderly, as it provides comfort and tranquility. It is also necessary to pray with the patient, to participate actively, narrowing the relationship with the patient reinforced by the Watson's Theory of Transpersonal Caring.

Benefits of prayer, as well as other types of spiritual care, should be extended to families, as they are part of the holistic approach, as Aquamarine evidences:

There was a little death in the process, and one of the daughters said that she wanted to bring the family to say goodbye. Coordination authorized. We made a circle around her mother and there we prayed, and at that moment there was disincarnation, right? It was a fantastic moment. A quiet disincarnate, and all the children, at that moment thanked and said that it could not have happened better. It is an event that marked me and I will never forget. To this day I feel good for being able to help and have contributed. (Aquamarine)

The said nurse had sensitivity to understand the suffering of the family, in addition to respect and appreciation of the belief. Having accepted the desire and participated in the prayer probably facilitated the embracement of the moment, besides the embracement. Empirical behavior was evidenced in addition to the exchange ratio, since the attitude benefited not only the family, but itself, translating humanized care. 
The solicitation of religious representatives, as far as possible, was also raised as a friar, pastor and "pai de santo" mentioned by Emerald, Diamond and Jade, in addition to spiritual surgery reports by Diamond. Sunstone and Sapphire added religious rituals, such as a popcorn bath and the use of musical instruments.

I take care of knowing his preferences, which he can also ask a priest to visit. It was patient that we already offered a musical instrument, it was of Candomblé, and I liked to beat the drums. (Emerald)

We try to meet everyone's demand for what we can. I need a pastor to come. And never let them lose faith, because it is very important to the treatment, and we see it. They get very attached. From doing spiritual surgery here. (Diamond)

It is to try as far as possible, meet those needs, if she has and likes to listen to the radio, will have the right to listen. If she likes to play her tambourine, as long as she does not bother anyone. (Sapphire)

Colleagues saw that people came from Candomble and wanted to bathe the popcorn, and the hospital respected. (Sunstone)

He asks for the presence of a priest, in short, a "pai de santo" [Shaman from the Afro-Brazilian religion called Candomblé]. (Jade)

Another form of spiritual care assistance was through the encouragement and embracement to the use of radio, television, in which they listen to religious music, placed by Sapphire. The diversity of beliefs, representativeness and receptivity of the nurses are perceived to the spiritual needs showing respect, understanding of the subjectivity of the other and the importance attributed to this dimension. Appreciation of respect was also present in some reports:

I understand that every elder, he must be respected in its entirety, his spirituality should be preserved, respected. Those elderly people who have the desire to go, we refer them. (Sunstone)

Their spiritual needs are something we have to be very careful about, right?! Even because they take everything very closely. They cherish that much, so we cannot disdain. (Topaz)

He asks for the presence of a priest, a "paide santo". A mentor and so it really has to be respected, and as far as it can be attended to. (Jade)

Some collaborators reinforced that the response to requests is important to reinforce the faith, since it contributes to the health and improvement of the quality of life (QoL) of these patients, as reported below:

And never let them lose faith, because it is very important to the treatment, and we see it, they get very attached. (Diamond)

In order for him to have faith, his belief improves to his clinical picture, because I believe it has a lot to do with. (Fluorite)

So he sticking to some religion, he gets more active, does not he? (Malachite)

Despite this context, Crystal stressed that he had difficulty in accessing the elderly's spiritual dimension who has a religion opposed to hers:
Being Catholic or Evangelical to help us, is easier. And ifyou are an elder of other religions, I do not know how to approach. If you're a candomblecris [Camdonblé follower] t, I have no idea. I do not have a very firm faith, but we can give support. I find it easier because it is, more or less my religion, but from another denomination, I honestly have no idea how to help. (Crystal)

Just as the dialogue narrows the relationship, the lack of ability to approach the spiritual dimension can refer to the attitude of carelessness, prejudice, insecurity, withdrawing the patient from the nurse and impairing the relationship and care. Scientific foundation and the ability to multidimensional care can avoid distancing the nurse/patient relationship, since the specificities of the individual's aging and subjectivity are essential for the association of body, mind and soul.

\section{DISCUSSION}

Watson's Theory of Transpersonal Caring is grounded in the existential spiritual approach that encompasses the art and science of nursing. To carry out this care, the elements of the Caritas Clinical Process are used, which enable its practical application and is composed of 10 elements ${ }^{(13)}$. Throughout the discussion, some of these elements will be resumed.

Religion/religiousness is part of the life of the elderly, especially in situations of suffering, frailty that can come during hospitalization, being part of spirituality of the human being. In this sense, the Watson's Theory of Transpersonal Caring considers, in element 10 of the Caritas Process, that the nurse needs to be attentive to spiritual care when referring to "Give openness and attention to the spiritual mysteries and existential dimensions of life-death, caring for one's own soul and that of being cared for"(13).

In this perspective, authors suggest that the nurse could participate with activities related to the search of internal forces for self-care and the other, as an example, To know what is important for oneself and respect what has meaning for the other; To keep a sacred space of healing for others, respecting their time and their need; To believe in the healing power of faith and hope; Encouraging the search for internal forces for care ${ }^{(13)}$. Thus, element 10 assists the nurse to care for the patient through a holistic view.

The moment of the dialogue, nurse/patient interaction and subjective relationship permeate the foundations of this theory, since the nurse must be able to grasp, understand the feelings and the intimate reason of the other, and can be through words and actions. Art is also established by expressions of feelings, since this professional perceived the need of the patient, is able to feel, demonstrate, and the other is able to capture and promote change in feelings ${ }^{(14)}$.

Nurses'speeches, when expressing dialogue as spiritual care, are consistent with literature ${ }^{(15)}$, considering the importance of interaction with the patient in this context. These professionals, when they observe manifestations of frailty, use words that refer to the spiritual dimension through encouragement and appreciation of faith.

Also in this direction, a study carried out with nurses who care for patients in palliative care has identified as their main spiritual needs belief, faith, hope, family support, forgiveness and love, 
demonstrating that these needs are contemplated through dialogue, since this favors the collection of information, as well as the narrowing of the link and listening ${ }^{(16)}$.

Thus encouragement to the spiritual dimension through communication converge with element 2 of the Clinical Caritas Process. To be authentically present, to strengthen, sustain, and honor the deep belief system and the subjective life-world of being cared for ${ }^{(13)}$. In this context, beliefs are valued and respected as positive influences on health. The nurse must cultivate faith and hope in something or someone besides himself, regardless of medical conduct or possibility of cure ${ }^{(17)}$. This type of encouragement leads to the valorization of the subjectivity of the individual, reinforcing the use of Watson's Transpersonal Human Care Theory, thus meeting the specificities and needs of the elderly.

Faced with this, in addition to encouraging words and beliefs, nurses could encourage more expressions of religious needs, understand the difficulties, the subjectivity and specificity of the being that cares for, giving more to the relationship and establishing trust.

Caregivers must be present, involved, supporting and valuing the patient's beliefs and subjectivity, that is, showing an interest in the other ${ }^{(13)}$. Personal manifestations and experiences need to be valued and felt so that care is intensified and nourished. Therefore, listening and recognition of feelings are relevant to each other, and may even be the greatest act of healing ${ }^{(17)}$.

It was noticed in the testimonies that little was reported about the need to listen to the elderly, where nurses expressed an incentive to beliefs and respect, but did not remit the importance of listening to the other. With this, it contrasts the forerunner of the Watson's Theory of Transpersonal Caring that postulates that this listening is essential, aiming to develop a humanized care.

The study nurses understand the need to encourage faith, as it positively influences the health of patients. Faced with this, suffering can generate a state of imbalance of harmony between world-mind/emotions-body-soul ${ }^{(14)}$.

The same theorist states that caregivers should express their feelings so that the empathic relationship is bilateral, through mutual respect ${ }^{(18)}$. Element 4 of the Clinical Caritas Process seeks to develop and sustain an authentic relationship of care, help and trust ${ }^{(13)}$. This is also worked out when nurses dialogue with patients, as it is an expression of embracement and an empathic attitude. The transpersonal relationship of caring, when it refers to empathy, is intertwined with the nurse's ability to identify and assimilate the feelings and the essence of the other ${ }^{(14)}$.

Element 9 of the Clinical Caritas Process is also identified in this context and recommends attending to basic human needs with satisfaction, preserving human dignity and integrity, as the nurse must attend not only to the demand of the physical body but also to the demand of the embodied spirit. Needs are interdependent and have the same importance and should therefore be valued $^{(17)}$. The needs of the elderly inherent to the aging process, and especially to the condition of suffering, vulnerability of illness and hospitalization are contemplated in this Process.

Religious practices become potent during aging. Routines, such as going to mass, procession and prayer of a third are activities considered for the adepts, because they enable spiritual comfort. The support for the elderly to achieve them should be offered, aiming not only care for the body, but also the spiritual ${ }^{(19)}$.

Spiritual care offers answers to the questions that involve meaning of life, pain, suffering and death, requiring nurses to develop the art of "being with patients". Given this, this professional needs to value this dimension in the relationship with the patients, as it corroborates positive results, among them healing, spiritual well-being and psychological adjustment ${ }^{(20)}$.

In this study, some nurses emphasized the encouragement of patients to prayer, but only two prayed with the patient. This practice is important to nourish the religiousness of the elderly and is representative because it is an encouragement to faith and is in harmony with element 10 of the Clinical Caritas Process. However, nurses should actively participate in this activity, as evidenced by elements 4 and 5 of this Process, by being present, supporting the expressions of positive and negative feelings as a deep connection with one's own spirit and that of being cared for $^{(13)}$. Thus, one can perceive the active participation of nurses in this context.

A study carried out with nurses showed that they considered that support for spiritual, emotional and religious aspects are relevant because they lead patients to embracement and tranquility, emphasizing that the power of prayer can cherish hours of emotional imbalance ${ }^{(21)}$.

Sensitivity, embracement and, especially, empathy were observed in the assistance of one of the nurses when she put herself in the place of the family member, understanding the meaning of the prayer, the benefit of it, participating in this moment. Such an attitude is corroborated by elements 4 and 5 of said Process.

The person who cares must have abstract characteristics, such as the understanding of the neighbor, as well as their own feelings, that is, sensitivity. In this context, the nurse's life history, the experience of his feelings, the multiple conditions of the other ${ }^{(14)}$ helps him to put himself in the place of the next. Thus, nurses value subjectivity, and develop humanization, basic principles of Watson's Theory of Transpersonal Caring.

Spiritual care is beneficial to the patient, just as it is to nurses, since it improves spiritual awareness and contentment at work, considered thus, a "therapeutic relationship" ${ }^{\prime 20}$. Spirituality is given responsibility to attribute meaning to the work of professionals who work in palliation, contributing to the strengthening as a human being promoting reflections on professional performance ${ }^{(22)}$.

A study shows that professionals have shown that the opportunity to offer comfort comes from spirituality. The provision of spiritual care and spirituality are responsible for the existential encounter between the patient in palliation and professionals involved. The offer of QoL to the patient is essential, such as welcoming the family ${ }^{(2)}$.

Spiritual care provided by the nurses of this study enabled the patients' requests to go to mass, permission for religious rituals, visits of representatives, use of media vehicles. Musical instruments are in line with the authors, since the spiritual needs of the elderly must be valued, contemplated, thus offering a holistic care.

Religiousness is used as a relevant emotional support that directly influences the mental and physical health of the elderly, in the face of situations of suffering ${ }^{(23)}$. A soul when it is disturbed by suffering, sadness, losses, among others, can generate in the body an imbalance and provoke a malaise, causing illnesses ${ }^{(14)}$. 
It should be noted that all such care provided to the spiritual dimension is in keeping with the Caritas Clinical Process, as discussed above. They also converge with the proposal presented by the NIC (Nursing Interventions Classification) that contemplates the standardized language system for nursing interventions. This brings interventions for the diagnoses of Spiritual Suffering; Impaired Religiousness, Impaired Individual Resilience ${ }^{(24)}$.

It is noticed that in the interventions suggested by the NIC, the nurse must act directly or indirectly. Most of the participants reported indirectly when they referred the elderly to religious activities, allowing rituals, reading, listening to music, among others. Others expressed active care, such as the encouragement of faith, dialogue, embracement and empathy, even though the minority reported participation in prayers.

Although the collaborators worked the spiritual dimension, one of them reported having difficulty in approaching the elder who has opposite religion. In this way, the nurse's spirituality can direct the form that provides care, being able to be responsible for that it develops or omits care ${ }^{(25)}$. It is necessary to know the different forms of manifestation of faith, to assist in spiritual interventions and to direct reflection on this dimension ${ }^{(26)}$. In addition to the beliefs of the elderly patient and the nurse, one should contemplate the Watson's Theory of Transpersonal Caring, which predicts that the nurse-patient relationship is a phenomenological field of understanding between two human beings, a follow-up given by specific moments of care that help the spiritual growth of both ${ }^{(22)}$.

This difficulty in accessing the patient's belief can be underpinned by element 6 of the Clinical Caritas Process, which postulates engaging in the individualized creative process of problem-solving. In this case, the nurse should assess the moment as a whole, using her knowledge, intuition, empiricism, ethics, and spiritual knowledge.

The nurse, for developing technical assistance, does not invest in scientific basis, and it is necessary to broaden the understanding about the offer of holistic care ${ }^{(27)}$. A study carried out in Jordan states that nurses considered the inclusion of knowledge about spirituality in the nursing course so that they develop greater awareness and ability to offer holistic care ${ }^{(28)}$. A study that surveyed the content of academic books observed that they worked on the subject inconsistently. With this, he concluded that it is necessary to make available to the spiritual dimension the relevant relevance so that this competence is mirrored in professional practice ${ }^{(29)}$.

Thus, the caring person must be able to help the elderly to face the suffering ${ }^{(19)}$. This care involves not only body, but also something not consistent, but existent and indispensable, the spirit. The intersubjectivity that transcends caring is eternal and will continue to be expanded, provided that knowledge is expanded. Transpersonal care is desired for the human being, since it is established space for the dignity and humanization ${ }^{(4)}$.

\section{Study limitations}

The study presents as a limitation the non-observation of how the nurses developed the spiritual care, since in some opportunities of observation of care, this type of care was not seen, perhaps due to the lack of opportunity of the moment. While awaiting the interviews, it was verified the accomplishment of administrative demands by the nurse.

\section{Contributions to Nursing}

The results of the study will help nurses to reflect and broaden their knowledge regarding the spiritual dimension, as well as the need to value this care provided to the elderly. As the spiritual dimension has been used as a coping strategy, this must be ensured, as it contemplates humanistic aspects, promotes wellbeing and improves quality of life.

\section{FINAL CONSIDERATIONS}

The spiritual dimension should be contemplated in care of nurses who approach the patient holistically. The valorization of this dimension feeds the human transpersonal care being observed in care of professionals of this study through the dialogue and embracement of spiritual needs. Participants evidenced the need for knowledge to access this dimension satisfactorily, as well as the understanding of their own spirituality.

\section{REFERENCES}

1. Keenan PM, MacDermott C. Prayer and Religion: Irish nurses caring for an intellectually disabled child who has died [Internet]. 2016 [cited $2018 \mathrm{Jul}$ 23];7(12):148. Available from: http://www.mdpi.com/2077-1444/7/12/148

2. Arrieira ICO, Thofehrn MB, Milbrath VM, Schwonke CRGB, Cardoso DH, Fripp JC. The meaning of spirituality in the transience of life. EsC Anna Nery [Internet] 2017 [cited 2018 Jun 19];21(1):e20170012. Available from: http://www.scielo.br/pdf/ean/v21n1/1414-8145-ean-2101-e20170012.pdf

3. Soares AS, Amorim MI. Qualidade de vida e espiritualidade em pessoas idosas institucionalizadas. Rev Port Enferm Saude Mental [Internet]. 2015 [cited 2017 Jan 10];(spe2):45-51. Available from: http://www.scielo.mec.pt/pdf/rpesm/nspe2/nspe2a08.pdf

4. Esperandio MR, Zarpelon M, Zorzi P, Silva TODO, Marques LF. Religiosidade/espiritualidade (R/E) em profissionais/trabalhadores da saúde. Inter Cult Comun [Internet]. 2015 [cited 2018 Jul 15];10(18):195-209. Available from: http://periodicos.pucminas.br/index.php/interacoes/ article/view/P.1983-2478.2015v10n18p195/9179.

5. Vieira DCR, Aquino TAA. Vitalidade subjetiva, sentido na vida e religiosidade em idosos: um estudo correlacional temas em psicologia [Internet] 2016 [cited 2017 Feb 10]; 24(2):483-94. Available from: http://www.redalyc.org/pdf/5137/513754278005.pdf 
6. Sampaio $A D$, Siqueira $\mathrm{HCH}$. Infuência da espiritualidade no tratamento do usuário oncológico: olhar da enfermagem. Ensaios Cienc Biol Agrar Saúde [Internet] 2016 [cited 2018 Aug 1];20(3):151-8. Available from: http://pgsskroton.com.br/seer/index.php/ensaioeciencia/article/view/4433

7. Miquelatto $M$, Silva L, Figueira $C B$, Santos $M R$, Szilit R, Ichikawa CRF. Espiritualidade de famílias com um ente querido em situação final de vida. Rev Cuidarte [Internet]. 2017 [cited 2018 Jan 20];8(2):1016-27 Available from: https://www.revistacuidarte.org/index.php/cuidarte/ article/view/391/798

8. Oliveira ALB, Menezes TMO. Significado da religião/religiosidade para a pessoa idosa. Rev Bras Enferm [Internet]. 2018 [cited 2018 Jul 14];71(suppl 2):823-9. Available from: http://www.scielo.br/pdf/reben/v71s2/pt_0034-7167-reben-71-s2-0770.pdf

9. Giske T, Cone PH. Discerning the healing path-how nurses assist patient spirituality in diverse health care settings. J Clin Nurs. 2015;24(1920):2926-35. doi: $10.1111 /$ jocn. 12907

10. Herdman TH, Kamitsuru S. NANDA International nursing diagnoses: definitions and classification, 2018-2020. New York: Thieme; 2018.

11. Scorsolini-Comin F. A religiosidade/espiritualidade no campo da saúde. Rev Cienc em Saúde [Internet] 2018 [cited 2018 May 18];8(2):1-2. Available from: http://200.216.240.50:8484/rcsfmit/ojs-2.3.3-3/index.php/rcsfmit_zero/article/viewFile/752/417

12. Bardin L. Análise de Conteúdo. 5. ed. Lisboa: Edições 70, 2016.

13. Tonin L, Nascimento JD, Lacerda MR, Favero L, Gomes IM, Denipote AGM. Guide to deliver the elements of the Clinical Caritas Process. Esc Anna Nery[Internet]. 2017 [cited 2017 Dec 18];21(4):e20170034. Available from: http://www.scielo.br/pdf/ean/v21n4/1414-8145-ean-21779465-EAN-2017-0034.pdf

14. Watson J. Enfermagem: ciência humana e cuidar uma teoria de Enfermagem. Trad. de João Enes. Loures: Lusociência; 2002.

15. Simão-Miranda TP, Monteiro LA, Carvalho CCC, Cordeiro LA, Chaves ECL, Leite MC. A dimensão espiritual no processo de cuidar da pessoa com câncer: uma revisão integrativa. Cul Cuid [Internet]. 2017 [cited 2017 Dec 18];21(47):14-21. Available from: https://rua.ua.es/dspace/ bitstream/10045/65749/1/CultCuid_47_02.pdf

16. Evangelista CB, Lopes MEL, Costa SFG, Batista PSS, Batista JBV, Oliveira AMM. Cuidados paliativos e espiritualidade: revisão integrativa da literatura. Rev Bras Enferm [Internet]. 2016 [cited 2017 Dec 18]; 69(3):554-63. Available from: http://www.redalyc.org/ html/2670/267046071024/

17. Watson J. Watson's theory of human caring and subjective living experiences: carative factors/caritas processes as a disciplinary guide to the professional nursing practice. Texto Contexto Enferm [Internet]. 2007 [cited 2018 Jan 11];16(1):129-35. Available from: http://dx.doi. org/10.1590/S0104-07072007000100016

18. Savieto RM, Leão ER. Assistência em Enfermagem e Jean Watson: uma refexão sobre a empatia. Esc Anna Nery. [Internet]. 2016 [cited 2018 Jan 11]; 20(1):198-202. Available from: http://www.redalyc.org/html/1277/127744318026/

19. Oliveira RM, Alves VP. A qualidade de vida dos idosos a partir da influência da religiosidade e da espiritualidade: cuidados prestados aos idosos institucionalizados em Caetité (BA). Revista Kairós Gerontologia. [Internet]. 2014 [cited 2017 Dec 18];17(3):305-27. Available from: https://revistas.pucsp.br/index.php/kairos/article/view/23208

20. Ramezani M, Ahmadi F, Mohammadi E, Kazemnejad A. Spiritual care in nursing: a concept analysis. Int Nurs Rev [Internet]. 2014 [cited 2017 Dec 18];61(2):211-9. Available from: https://onlinelibrary.wiley.com/doi/epdf/10.1111/inr.12099

21. Monteiro ACM, Rodrigues BMRD, Pacheco STA, Pimenta LSP. A atuação do enfermeiro junto à criança com câncer: cuidados paliativos. Rev Enferm UERJ [Internet]. 2014 [cited 2018 Aug 10];2(6):778-83. Available from: http://www.e-publicacoes.uerj.br/index.php/ enfermagemuerj/article/view/15665/12267

22. Arrieira ICO, Thofehrn MB, Porto AR, Moura PMM, Martins CL, Jacondino MB. Spirituality in palliative care: experiences of an interdisciplinary team. Rev Esc Enferm USP [Internet]. 2018 [cited 2018 Aug 11]; 52: e03312. Available from: http://www.scielo.br/pdf/reeusp/v52/en_00806234-reeusp-S1980-220X2017007403312.pdf

23. Zenevicz L, Moriguchi Y, Madureira V. A religiosidade no processo de viver envelhecendo. Rev Esc Enferm USP [Internet]. 2013 [cited 2018 Aug 11];47(2):433-9. Available from: http://www.periodicos.usp.br/reeusp/article/view/58523

24. Bulechek GM, Butcher HK, Dochterman JM, Cheryl MW. NIC Classificação das intervenções de enfermagem. 6a ed. Rio de Janeiro: Elsevier; 2016

25. Nascimento LC, Santos TFM, Oliveira FCS, Pan R, Santos MF, Rocha SMM. Espiritualidade e religiosidade na perspectiva de enfermeiros. Texto Contexto Enferm [Internet]. 2013 [cited 2018 Aug 11]; 22(1):52-60. Available from: http://dx.doi.org/10.1590/S0104-07072013000100007

26. Hefti R, Esperandio MRG. O modelo interdisciplinar de cuidado espiritual: uma abordagem holística de cuidado ao paciente. Horizonte [Internet] 2016 [cited 2018 Jun 27];14(41):13-47. Available from: http://periodicos.pucminas.br/index.php/horizonte/article/ viewFile/P.2175-5841.2016v14n41p13/9373

27. Jesse E, Alligood MR. Jean Watson: Watson's Philosophy and Theory of Transpersonal Caring. In: Alligood MR. Nursing Theorists and their work. 8a ed. Maryland Heights, Mosby/Elsevier: 2018.

28. Melhem GAB; Zeilani RS; Zaqqout OA; Aljwad Al; Shawagfeh MQ; Al-Rahim MA. Nurses' perceptions of spirituality and spiritual care giving: a comparison study among all health care sectors in Jordan. Indian J Palliate care [Internet] 2016 [cited 2018 Aug 12];22(1):42-9. Available from: http://www.jpalliativecare.com/article.asp

29. Timmins F, Neill F, Murphy M, Begley T, Sheaf G. Spiritual care competence for contemporary nursing practice: a quantitative exploration of the guidance provided by fundamental nursing textbooks. Nurse Educ Pract [Internet] 2015 [cited 2018 Ago 10];15(6):485-91. Available from: https://www.ncbi.nlm.nih.gov/pubmed/25819014 